\title{
THE USE OF FLUORESCENCE SPECTROSCOPY TO ASSESS THE DEGREE OF OVERHEATING OF HONEY
}

\section{ZASTOSOWANIE SPEKTROSKOPII FLUORESCENCYJNEJ DO OCENY STOPNIA PRZEGRZANIA MIODU}

\author{
Department of Commodity Science and Quality Management, Gdynia Maritime University, Poland
}

\begin{abstract}
Streszczenie. Proces ogrzewania miodu, stosowany w celu jego dekrystalizacji, prowadzony zwłaszcza w zbyt wysokiej temperaturze oraz w bardzo długim czasie, może prowadzić do niekorzystnych zmian chemicznych. Celem pracy było zastosowanie spektroskopii fluorescencyjnej do oceny stopnia przegrzania miodów odmianowych. Materiał badawczy stanowiło 20 próbek miodów różnych odmian (wielokwiatowego, rzepakowego, spadziowego liściastego, spadziowego ze spadzi iglastej, gryczanego), które były ogrzewane w różnej temperaturze (w $40,60,80^{\circ} \mathrm{C}$ przez $48 \mathrm{~h}$ oraz mikrofalowo, w $90^{\circ} \mathrm{C}$, w czasie do $10 \mathrm{~s}$ ). Przygotowane próbki miodów oceniano, oznaczając zawartość 5-HMF oraz liczbę diastazową metodami spektrofotometrycznymi; wykonano także widma fluorescencji, które pozwoliły na odróżnienie próbek miodu ze względu na ich różne pochodzenie botaniczne. Wykazano, iż w wyniku różnych sposobów ogrzewania (w 40,60, $80^{\circ} \mathrm{C}$, mikrofalowo) próbki miodów z różnych źródeł botanicznych zachowywały się podobnie, biorąc pod uwagę zawartość 5-HMF i wartości liczby diastazowej oraz widma fluorescencyjne. Najwyższą zawartością 5-HMF oraz najmniejszą liczbą diastazową charakteryzowały się, niezależnie od odmiany, miody ogrzewane $w$ temperaturze $80^{\circ} \mathrm{C}$. Analizując widma fluorescencyjne, można zauważyć, że były one bardzo podobne w przypadku miodów ogrzewanych w temperaturze $40^{\circ} \mathrm{C}, 60^{\circ} \mathrm{C}$ oraz w piecu mikrofalowym. Jedynie widma fluorescencji miodów ogrzewanych w temperaturze $80^{\circ} \mathrm{C}$ różniły się istotnie od widm pozostałych próbek. Oznacza to, że spektroskopia fluorescencyjna może być stosowana tylko w celu wykrycia ekstremalnego przegrzania miodu.
\end{abstract}

Key words: honey, 5-HMF, diastase activity, overheating honey, fluorescence spectroscopy. Słowa kluczowe: miód, 5-HMF, liczba diastazowa, ogrzewanie miodu, spektroskopia fluorescencyjna.

\section{INTRODUCTION}

„Honey is the natural sweet substance produced by Apis mellifera bees from the nectar of plants or from secretions of living parts of plants or excretions of plant-sucking insects on the living parts of plants, which the bees collect, transform by combining with specific substances of their own, deposit, dehydrate, store and leave in honeycombs to ripen and mature" (Dyrektywa Parlamentu Europejskiego i Rady 2014/63/UE z dnia 15 maja 2014 r. zmieniająca dyrektywę Rady 2001/110/WE odnoszącą się do miodu). This product in unchanged character has an important nutritional value and therapeutic, prophylactic properties.

Corresponding author - Adres do korespondencji: Natalia Żak, Department of Commodity Science and Quality Management, Gdynia Maritime University, Morska 81-87, 81-225 Gdynia, Poland, e-mail: n.zak@wpit.am.gdynia.pl 
According to the classification, the main types of honey are floral or nectar honey (honey obtained from plant nectar) and honeydew honey (honey obtained from secretions of sucking insects). These raw materials used by bees are mainly responsible for organoleptic characteristics (taste, smell, colour), chemical composition and properties of individual honey botanical origin. However, not only the raw materials have an important impact on the final quality of the honey. Another aspect that is important in formation the quality of honey is the way how the honey is stored and prepared for consumption by the beekeepers. The big risk is related to the possibility of lowering the value of honey by the process of heating the honey to recrystallize it. Then its spilling into the unit packaging. Crystallization is a natural process, mainly dependent on the botanical origin of honey and the external factors. This process does not reduce the quality of honey, but consumers prefer liquid honey. In order to meet customer requirements manufacturers use honey recrystallization (liquidation), which may have a negative effect on the properties of honey (Turhan et al. 2008; Śliwińska et al. 2012; Wilczyńska 2012; Kowalski 2013).

Honey heat treatment, especially in a high temperatures and for a very long time, can result a chemical changes including: decrease enzymatic activity (including diastase (amylase) degradation), thermal degradation of vitamins and nutrients, 5-HMF formation and other Maillard reaction products or darkening the colour of honeys (Śliwińska et al. 2012).

Previous studies in order to find out honey overheating are time-consuming and costly. The aim of this study was to attempt to use fluorescence spectroscopy to assess the grade of overheating of honey.

\section{MATERIAL AND METHODS}

20 samples of honeys from Poland were investigated. The honeys, provided by local beekeepers association from Pomeranian province, were harvested in 2016 . The investigated samples consisted of 4 honeys from 5 botanical origin: rape, leaf honeydew, multifloral, pine honeydew, buckwheat. Honeys were heated in four ways:

- conventional method - at $40^{\circ} \mathrm{C}$ for 48 hours, with forced air circulation;

- conventional method - at $60^{\circ} \mathrm{C}$ for 48 hours, with forced air circulation;

- conventional method - at $80^{\circ} \mathrm{C}$ for 48 hours, with forced air circulation;

- short-term influence to microwave radiation - microwave power $750 \mathrm{~W}, 10 \mathrm{~s}$.

During heating in the microwave, the temperature inside the samples was immediately investigated $\left(85-90^{\circ} \mathrm{C}\right.$ in most samples) and then quickly cooled and stored at room temperature without light until analysis (no longer than 48 hours). In all heated honeys (conventional and microwave) determined the diastase activity, 5-HMF content, and fluorescence spectroscopy measurements were measured on the surface of the sample.

Chemical composition of these honeys were determined according to standards for honey (Polska Norma PN-88/A-77626 Miód pszczeli, 1988), using the following methods of analysis.

\section{The 5-hydroxymethylfurfural measurements}

The 5-hydroxymethylfurfural (5-HMF) content was determined by measuring the absorbance of the test sample at $550 \mathrm{~nm}$ with respect to water as a zero sample. For this purpose $2 \mathrm{ml}$ of a $20 \%$ honey solution was mixed with $1 \mathrm{ml}$ of barbituric acid and $5 \mathrm{ml}$ of p-toluidine. The zero sample was prepared in the same way as barbituric acid was excluded. 
The 5-HMF content in $1 \mathrm{~kg}$ of honey was calculated using the formula: $5-\mathrm{HMF}=192^{*} \mathrm{ABS}$, where 192-conversion factor, ABS-absorbance of the test sample (PN-88/A-77626; Rozporządzenie Ministra Rolnictwa i Rozwoju Wsi z dnia 30 lipca 2015 r.).

\section{Diastatic activity measurements}

Diastatic activity is defined as the amount of enzyme that converts $0,01 \mathrm{~g}$ of starch to a particular end point within one hour at $40^{\circ} \mathrm{C}$. The diastatic activity of honey was determined by photometric method in which starch conjugated with blue dye was used as substrate. It is hydrolysed by amylase, resulting in water-soluble starch chain fragments, which form 23 blue dye compounds. Their absorbance was measured spectrophotometrically at a wavelength of $620 \mathrm{~nm}$, against water as a zero test. The absorption of the solution is proportional to the diastatic activity of the sample. For this purpose, $5 \mathrm{ml}$ of a $10 \%$ honey solution was mixed with $5 \mathrm{ml}$ of acetate buffer, then thoroughly stirred and stored for 15 minutes in a water bath at $40^{\circ} \mathrm{C}$. After this time, a test tablet for $\alpha$-amylase activity was added to each test, thoroughly shaken and incubated at $40^{\circ} \mathrm{C}$ in a water bath. After 15 minutes, $1 \mathrm{ml}$ of $0,1 \mathrm{M}$ sodium hydroxide was added, mixed and filtered through a filter paper. The filtrate was used to measure absorbance at a wavelength of $620 \mathrm{~nm}$ using water as a reference sample. The results were calculated as the diastatic value number $(L D)$ using the following relationships: $L D=28,2 \times \Delta 620+2,64$, where $\Delta A 620$ - is the difference in extinction of the tested honey solution and blind test, 28,2 and 2,64 - constant consideration of the relationship between diastatic activity of honey (Rozporządzenie Ministra Rolnictwa i Rozwoju Wsi z dnia 30 lipca 2015 r.).

\section{Fluorescence measurements}

The studies were carried out using a set-up based on the Fluorescence Spectrophotometer F-7000 Hitachi, Japan. A special adapter was built for it in order to change its traditionalmeasurement range (Gębala 2009; Gębala and Przybyłowski 2010). The dimensional fluorescence spectra were measured at room temperature. The fluorescence spectra were obtained by recording the emission spectra (from 220 to $560 \mathrm{~nm}$ with a $10 \mathrm{~nm}$ step) corresponding to excitation wavelengths ranging between 200 and $450 \mathrm{~nm}$ (with a $5 \mathrm{~nm}$ step) and automatically normalized to the excitation intensity by the instrument.

All analysis were done triplicate. The statistical analysis involved the calculation of the basic measures: the mean value. To determine the effect of heating the honey to test the quality parameters by use analysis of variance (ANOVA). Statistical hypotheses were verified at significance level $p=0.05$.

\section{RESULTS AND DISCUSSION}

Hydroxymethylfurfural (5-HMF) content is a parameter used to evaluate the freshness of honey. According to literature data (Śliwińska el al. 2012; Al-Diab and Jarkas 2015; Pasias et al. 2017) the heating temperature of honey is a important effect on the content of Hydroxymethylfurfural (5-HMF). Exceeding the maximum levels of 5-HMF in honey $(40 \mathrm{mg} / \mathrm{kg})$ indicates overheating of honey and too long time of storage. Figure 1 shows changes in $5-\mathrm{HMF}$ content of honey under conventional and microwave heating. Analysis showed that 
the average content of 5-HMF in the heated honey reduced and this was statistically important $(p<0.05)$. The analyzes indicated that heating for $48 \mathrm{~h}$ at low temperatures (up to $40^{\circ} \mathrm{C}$ ) and short-term microwave heating for several seconds to $90^{\circ} \mathrm{C}$ did not affect the increase of 5 -HMF content in honey. In the case of honeys heated to $80^{\circ} \mathrm{C}$ and $60^{\circ} \mathrm{C}$ for $48 \mathrm{~h}$, the honeys showed a significant exceeding the norm of the 5-HMF content. Which reflects the impact of temperature on the quality of the honey during storage. Bartakova et al. (2011) also demonstrated that, in the case of microwave heating, the increase in 5-HMF content may take place after the heating time of honey. In conventional heating, the increase in temperature to $50^{\circ} \mathrm{C}$ or higher may cause a significant increase in 5-HMF in honey (Tosi et al. 2002, 2004; Turhan et al. 2008).

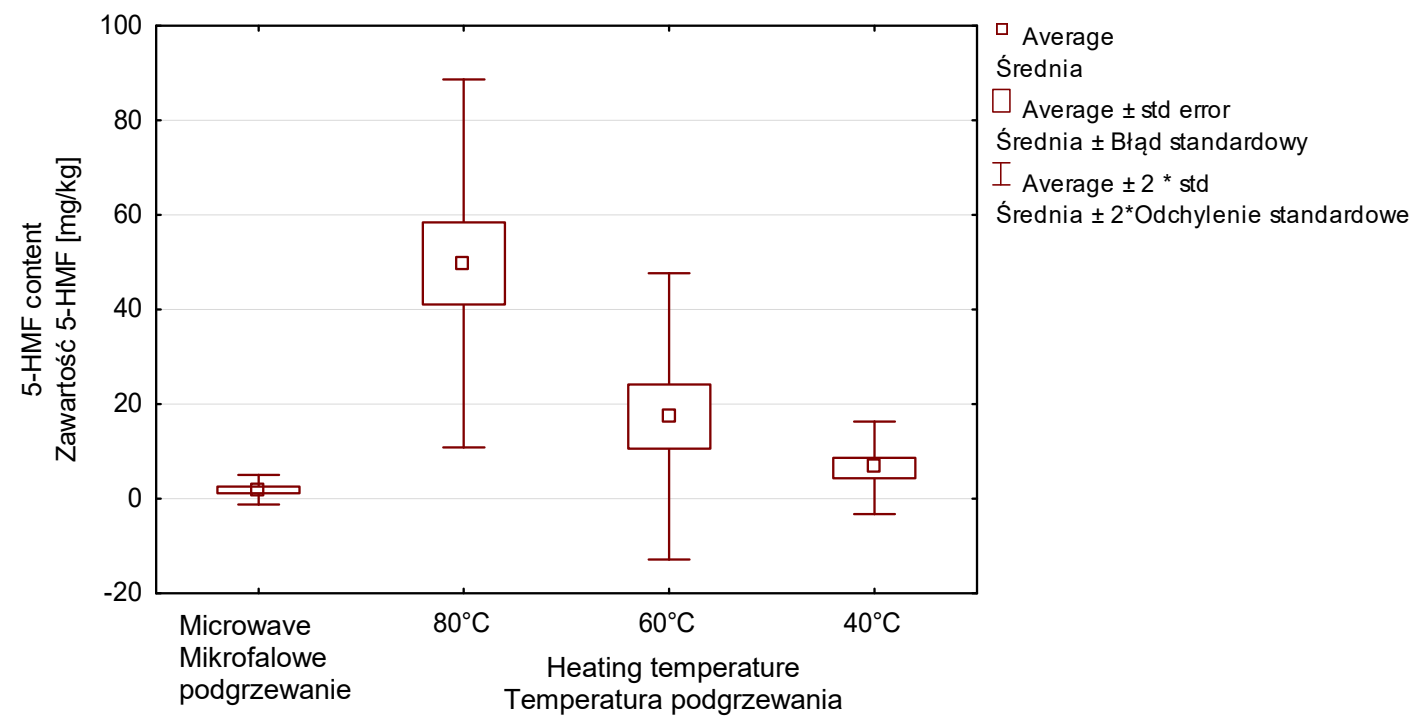

Fig. 1. Content of 5-HMF for heated honeys

Ryc.1. Zawartość 5-HMF w podgrzewanych miodach

For different botanical origin of honey (Fig. 2), light honeys (rape, multifloral) exhibits significant activity on the formation of 5 -HMF during honey storage at $80^{\circ} \mathrm{C}$ for $48 \mathrm{~h}$. Dark honeys are characterized by a higher resistance to $5 \mathrm{HMF}$ formation during heating and especially at $80^{\circ} \mathrm{C}$.

The diastase activity is one of the most important parameters indicating the high quality of honey. It is an indicator of honey enzymatic activity, and may also indicate that honey is falsified with sugar syrup (Pasias et al. 2017). The value diastase activity should be higher than 8. The studies carried out in this paper have confirmed that heating influences on the enzymatic activity of honey. The statistical analysis confirms that it is a important influence ( $p=0.0139$ ). It can be seen (Fig. 3 ) that the increase of temperature to $90^{\circ} \mathrm{C}$ associated with microwave heating of honey results in a important reduction in the enzyme activity shown as a diastase number, but long-term healing at $80^{\circ} \mathrm{C}$ causes to reduction the activity to 0 . Not only the temperature is important, we can also see that the time for heating is very important for diastase activity. For example in the temperature $60^{\circ} \mathrm{C}$ is the same result of enzymatic activity of honey like with microwave heating (Fig. 3). 


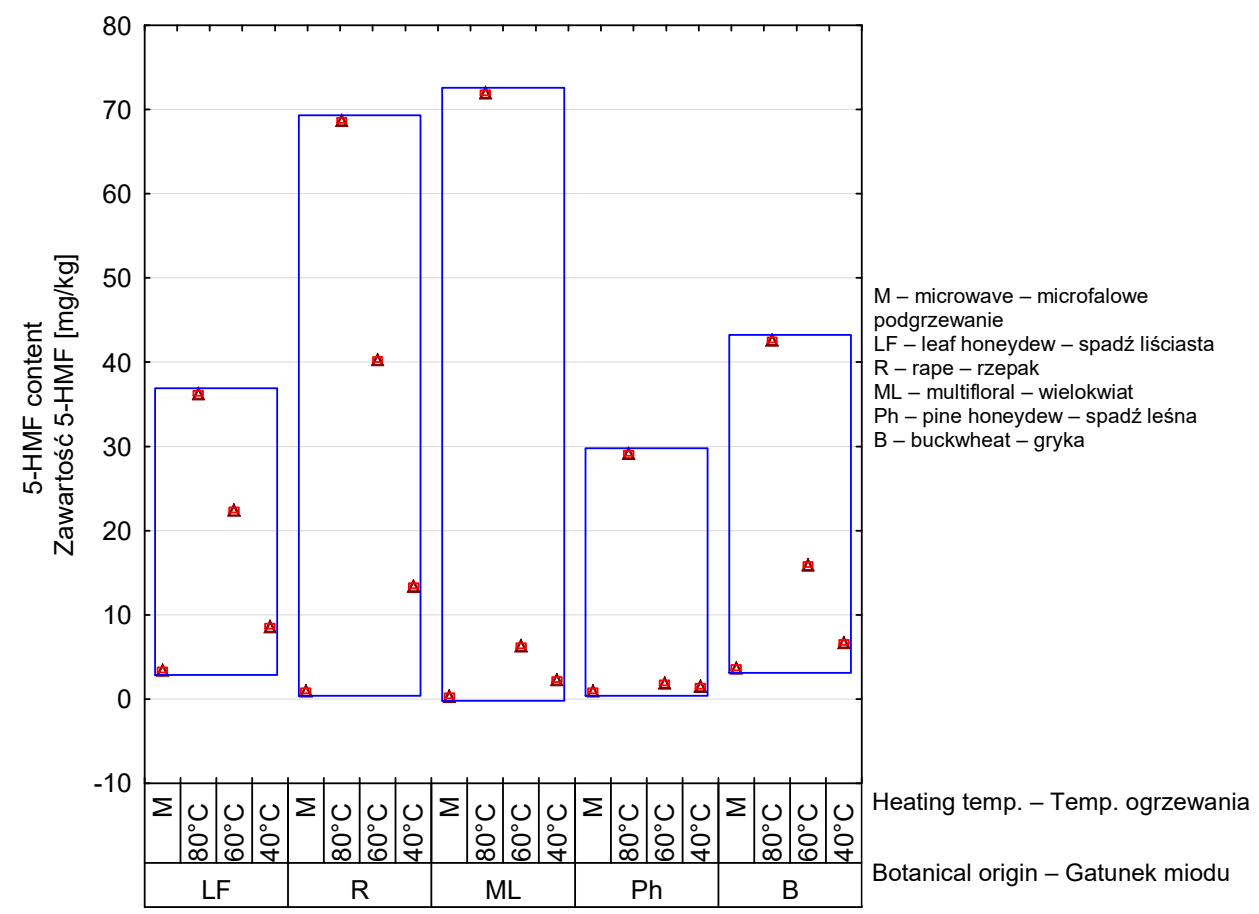

Fig. 2. Content of 5-HMF for heated honeys with regard to their botanical origin Ryc. 2. Zawartość 5-HMF w podgrzewanych miodach gatunkowych

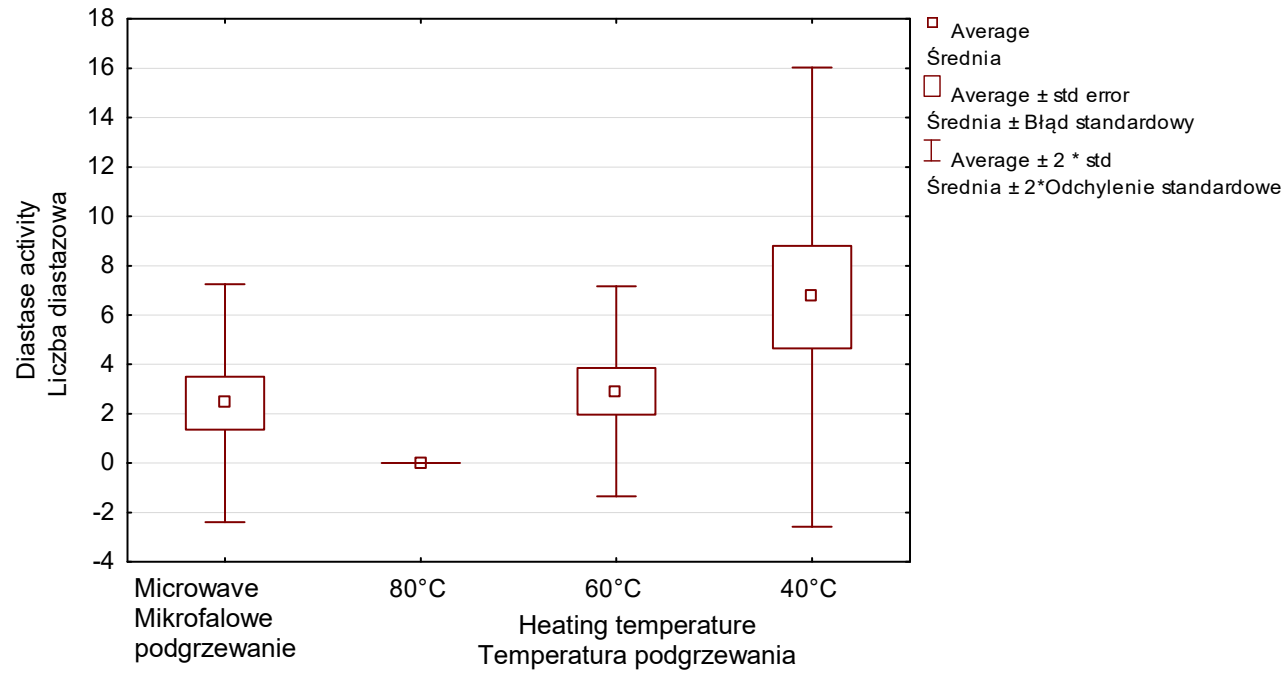

Fig. 3. Diastase activity for a heated honeys

Ryc. 3. Liczba diastazowa miodów podgrzewanych

Figure 4 shows the enzyme activity in the case of botanical origin group by honey. The rape and multifloral honeys were most stable than the other samples. It can be seen that dark honeys are characterized by a higher diastase activity than light honeys (Fig. 4).

In order to determine the necessary range of fluorescence measurement for each of the honey samples, determined the total spectra. These spectra are different. As a result of fluorescence spectroscopy, it can be seen that total fluorescence spectra is depend of the 
honey botanical origin. Below on the Fig. $5 a$ to $5 \mathrm{e}$ were shown the total spectra of honeys different botanical origin. Those samples were heated at $40^{\circ} \mathrm{C}$. Numbers in the frame to the right of the graphs indicate the intensity of light emission of a given wavelength $\lambda_{f}$ when excited by light at wavelength $\lambda_{w}$. The same results were presented by Gębala, (2009) and Lenhardt et al. (2015).

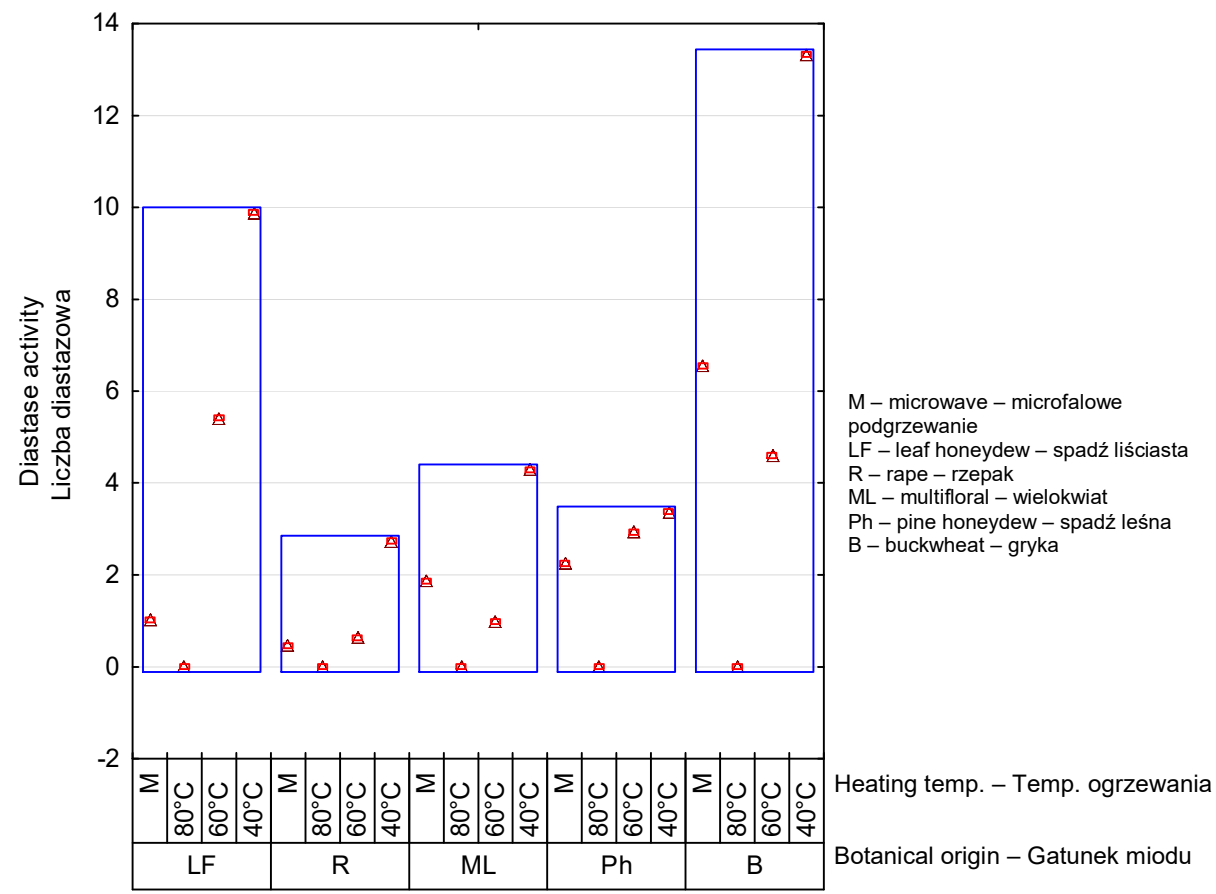

Fig. 4. Diastate activity for heated honey with regard to their botanical origin Ryc. 4. Liczba diastazowa gatunkowych miodów podgrzewanych

a

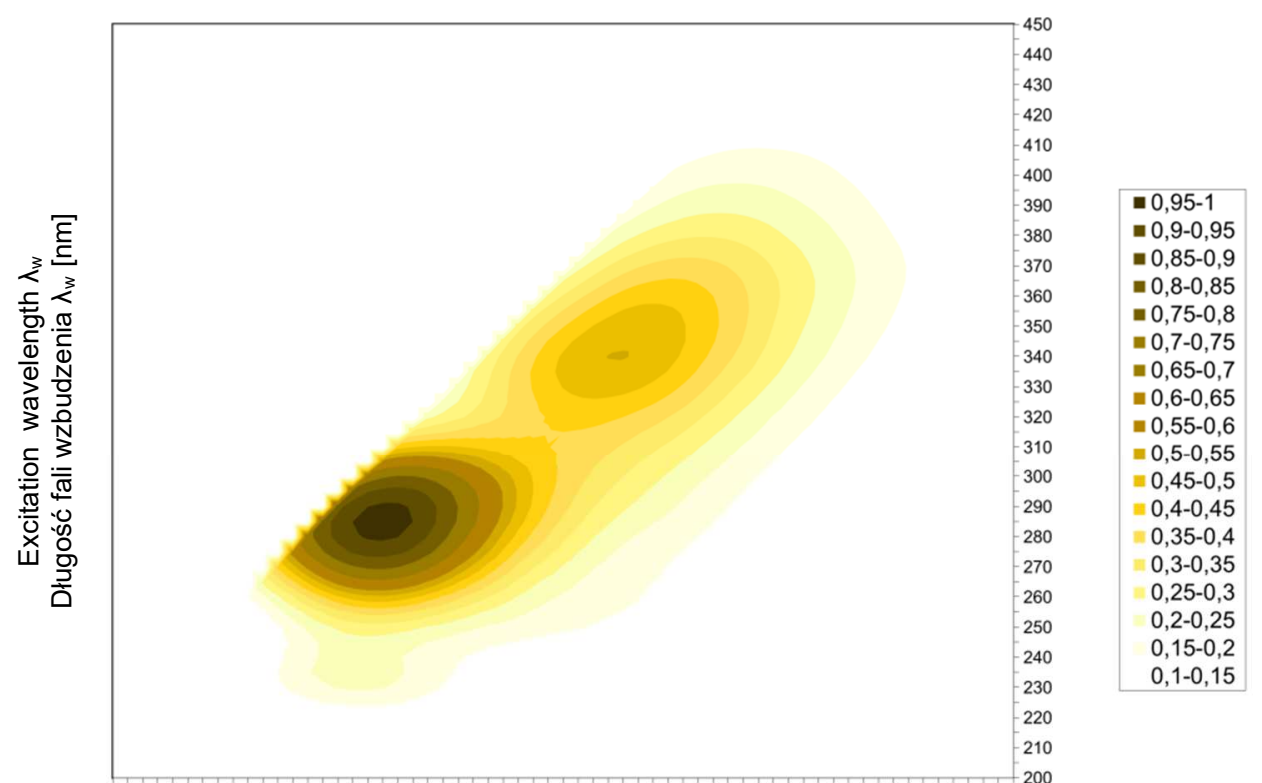

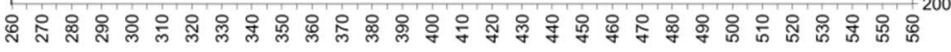

Emission wavelength $\lambda_{f}$

Długość fali emisji $\lambda_{\mathrm{f}}[\mathrm{nm}]$ 

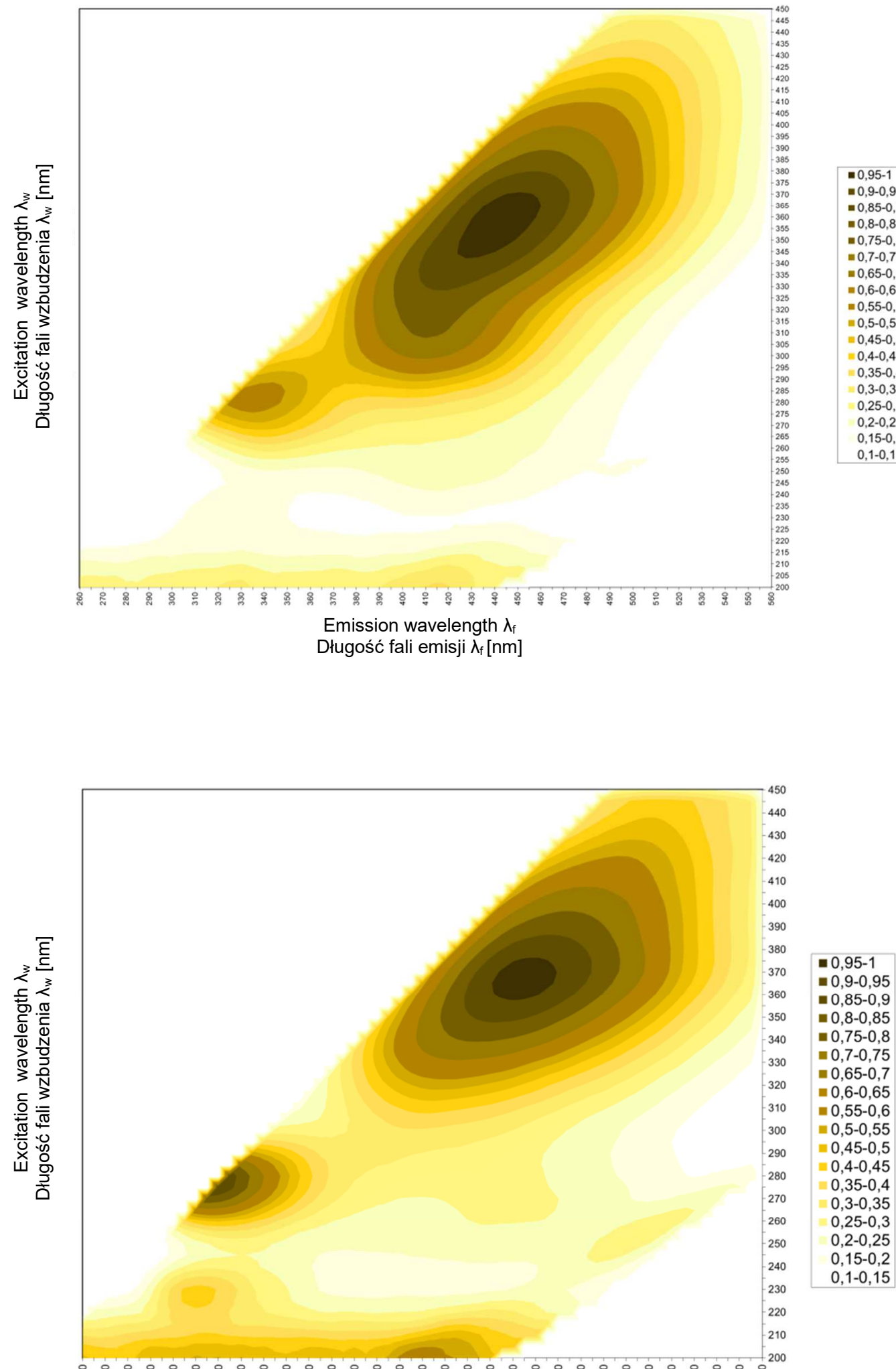

还梌总总

Emission wavelength $\lambda_{f}$

Długość fali emisji $\lambda_{\mathrm{f}}[\mathrm{nm}]$ 


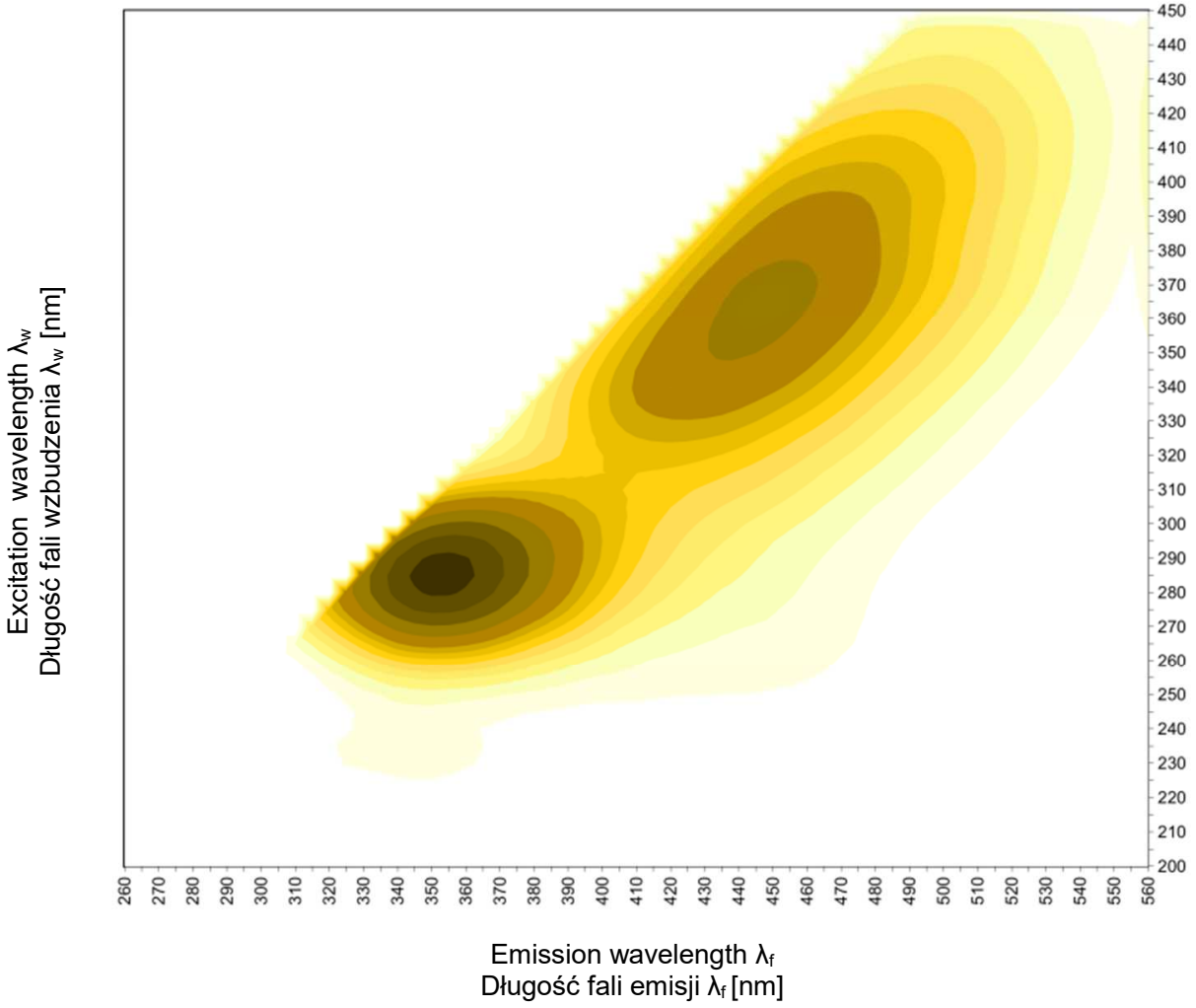

e

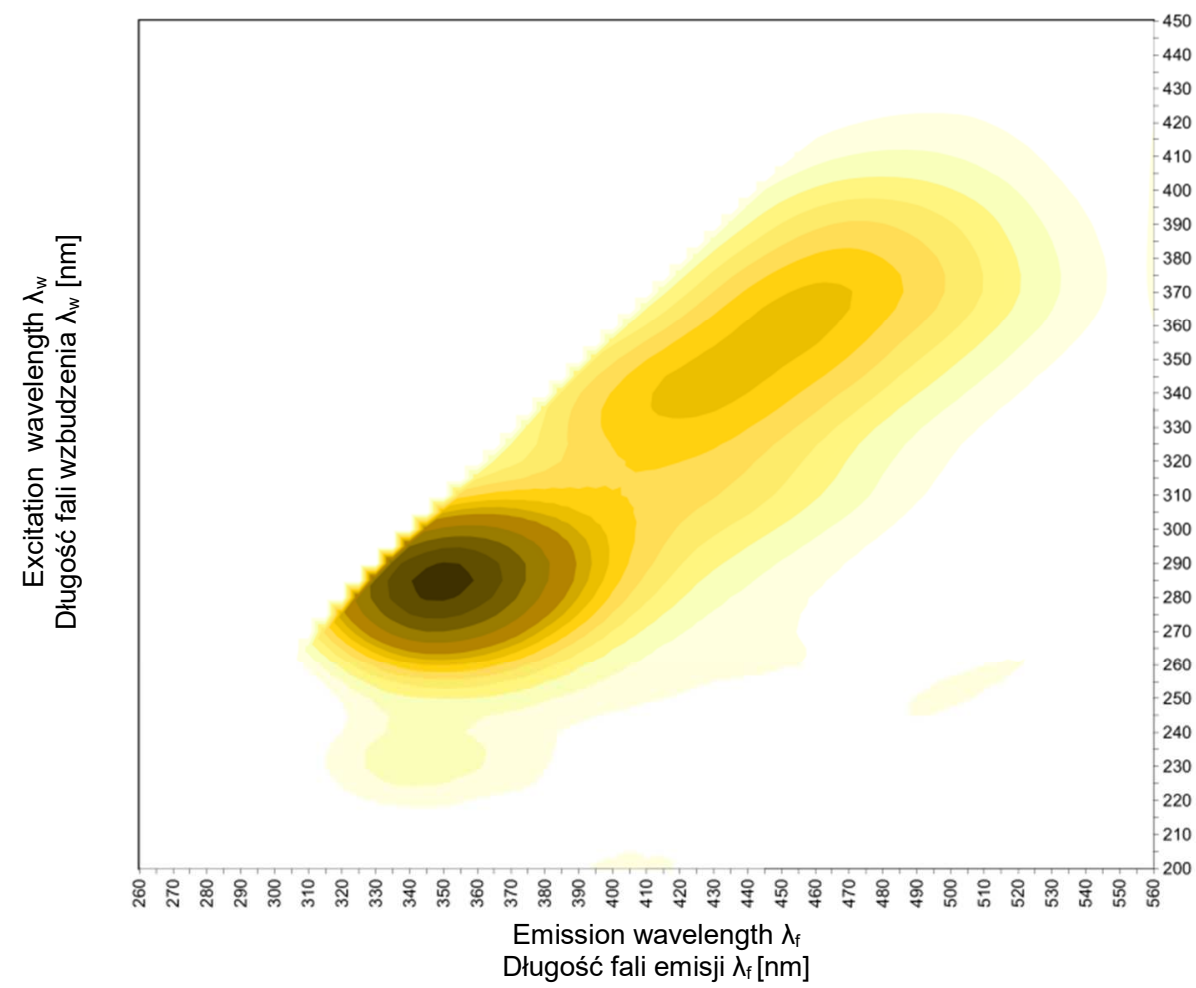

Fig. 5. Total fluorescent spectrum of honey heated in temperature $40^{\circ} \mathrm{C}$ : a - rape, $\mathrm{b}$ - pine honeydew, $c$ - buckwheat, $d$ - leaf honeydew, e - multifloral

Ryc. 5. Zupełne widmo fluorescencji dla miodów podgrzewanych w temperaturze $40^{\circ} \mathrm{C}$ : a - miód rzepakowy, b - miód spadziowy leśny, c - miód gryczany, d - miód spadziowy liściasty, e - miód wielokwiatowy 
Because of the difficult identification and analysis of spectra, it was found that the most important information is contained in the synchronous cross-sections of these spectra obtained at $\Delta \lambda=60 \mathrm{~nm}$, which are shown in Fig. 6a to 6e.

a

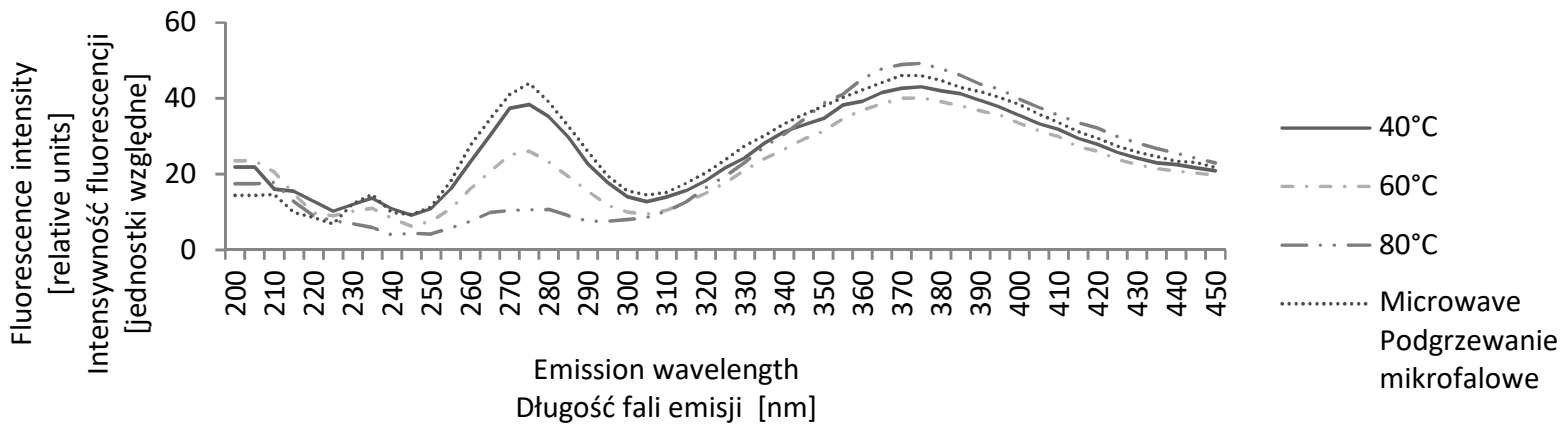

b

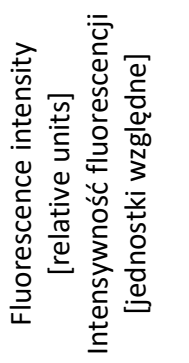

140
120
100
80
60
40
20
0
-20

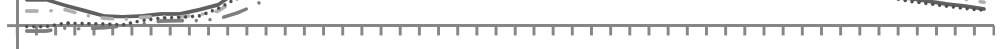

20200215230245260275290305320335350365380395410425440

Emission wavelength

Długość fali emisji [nm]

C

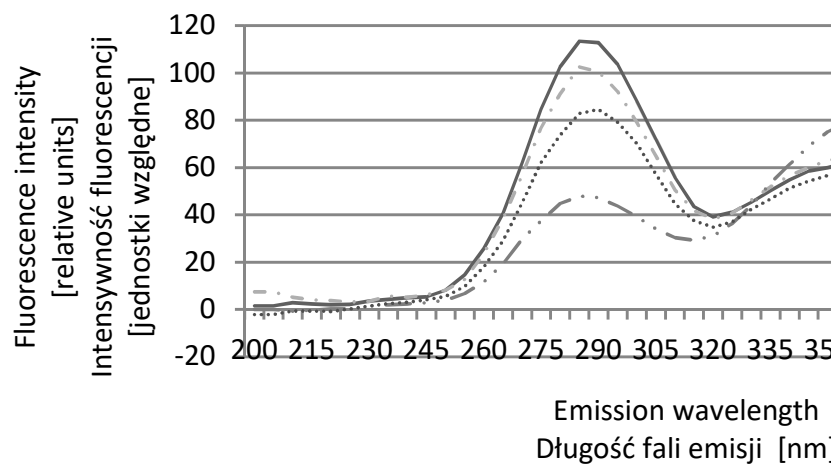

d

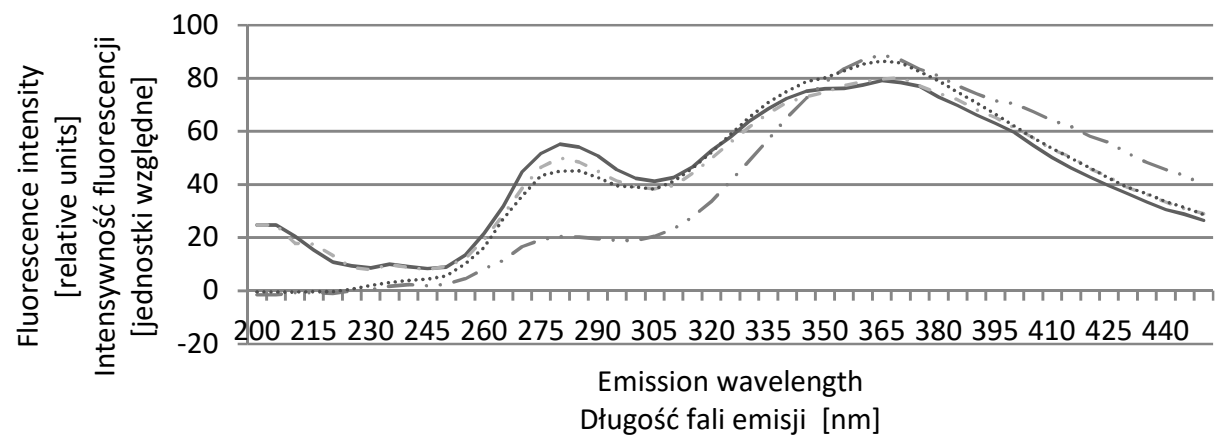

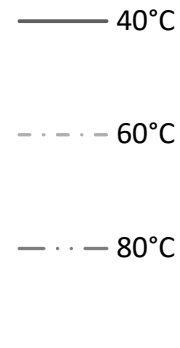

Microwave Podgrzewanie mikrofalove
Microwave Podgrzewanie mikrofalowe

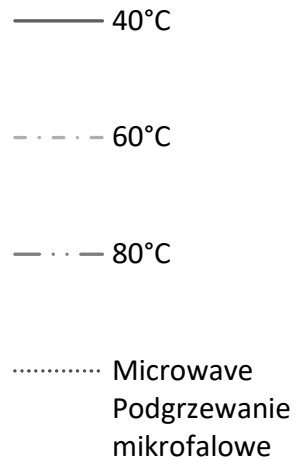


e

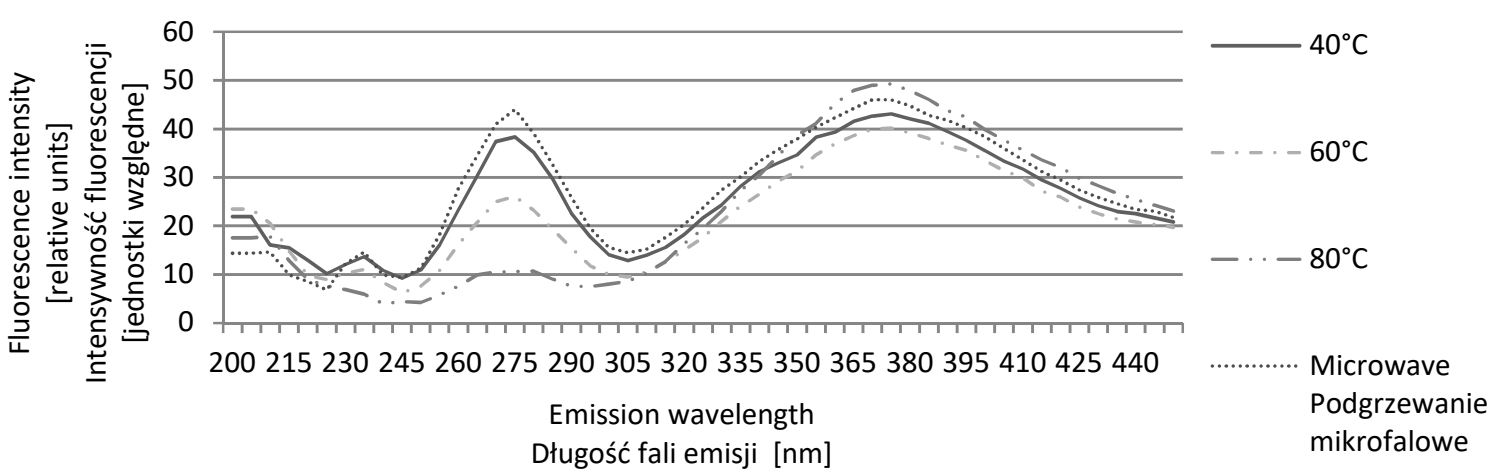

Fig. 6. Different fluorescence spectra of honey heated at different temperatures: $a-$ rape, $b$ - pine honeydew, c - buckwheat, $d$ - leaf honeydew, e - multifloral

Ryc. 6. Widma synchroniczne miodów podgrzewanych w różnej temperaturze: a - miód rzepakowy, b - miód spadziowy leśny, c - miód gryczany, d - miód spadziowy liściasty, e - miód wielokwiatowy

Figure 6a shows the set of synchronic spectra for rapeseed honeys obtained at $\Delta \lambda=60$ $\mathrm{nm}$. There is a noticeable tendency for up to three emission excitances: $235 \mathrm{~nm}, 275 \mathrm{~nm}$, $375 \mathrm{~nm}$ for microwave-heated honeys and heated at $40^{\circ} \mathrm{C}$ and $60^{\circ} \mathrm{C}$. Only the honey heated at $80^{\circ} \mathrm{C}$ shows a distinct flattening of synchronous fluorescence spectra at two emission maxima ( $235 \mathrm{~nm}$ and $275 \mathrm{~nm}$ ) for honeys heated in the remaining temperatures.

Figure $6 \mathrm{~b}$ shows the set of synchronic spectra for multifloral honeys obtained at $\Delta \lambda=60 \mathrm{~nm}$. There is a noticeable tendency for up to one emission excitances $(285 \mathrm{~nm})$ for microwave-heated honeys, heated at $40^{\circ} \mathrm{C}$ and $60^{\circ} \mathrm{C}$. Only the honey heated at $80^{\circ} \mathrm{C}$ shows a distinct flattening of synchronous fluorescence spectra at one emission maxima ( $285 \mathrm{~nm})$ and $275 \mathrm{~nm}$ ) for honey heated in the remaining temperatures. There is also a tendency for maximum emission at $365 \mathrm{~nm}$ compared to the other samples of multifloral honey.

In the case of leaf honeydew honey heated in different temperatures shows a trend of up to two maxima $(280 \mathrm{~nm}, 365 \mathrm{~nm})$. However, for honey heated at $80^{\circ} \mathrm{C}$, the maximum $(280 \mathrm{~nm})$ is observed to be more flat. Its height at $365 \mathrm{~nm}$ is slightly higher than honeys heated at $40^{\circ} \mathrm{C}, 60^{\circ} \mathrm{C}$ and microwaves (Fig. 6c).

Taking into account the pine honeydew honey heated in $40^{\circ} \mathrm{C}$ and $60^{\circ} \mathrm{C}$ is characterized by three different maxims: $200 \mathrm{~nm}, 275 \mathrm{~nm}, 365 \mathrm{~nm}$. The microwave-heated honey is characterized by much lower spectrum in the spectrum of $200 \mathrm{~nm}$ to $235 \mathrm{~nm}$. The same trend is with honey heated at $80^{\circ} \mathrm{C}$. It is noticeable that this honey is characterized by a significantly lower spectral height in the range of $250 \mathrm{~nm}$ to $300 \mathrm{~nm}$ and higher in the range of $390 \mathrm{~nm}$ to $450 \mathrm{~nm}$. In the range of the range of $345 \mathrm{~nm}$ to $390 \mathrm{~nm}$ the heated honeys at different temperatures $\left(40^{\circ} \mathrm{C}, 60^{\circ} \mathrm{C}, 80^{\circ} \mathrm{C}\right)$ have similar spectrum. Only microwave-heated honey exhibits a slightly higher fluorescence spectrum in this regard (Fig. 6d).

Buckwheat honey, heated at different temperatures $\left(40^{\circ} \mathrm{C}, 60^{\circ} \mathrm{C}\right.$ and microwave $)$ is characterized by two distinct maxims: $275 \mathrm{~nm}$ and $375 \mathrm{~nm}$. But it can be seen that the spectrum of honey heated at $80^{\circ} \mathrm{C}$ is flatter and much lower in $200-310 \mathrm{~nm}$ and has not visible maximum at $275 \mathrm{~nm}$ than the other heated honeys $\left(40^{\circ} \mathrm{C}, 60^{\circ} \mathrm{C}\right.$ and microwave). Its maximum is slightly higher at $375 \mathrm{~nm}$ than the other honeys (Fig. 6e). 


\section{CONCLUSIONS}

1. The methodology proposed in this contribution allowed distinguishing honey samples due to their different botanical origin by the simple and fast analysis of their fluorescence spectra.

2. As a result of different ways of heating $\left(40^{\circ} \mathrm{C}, 60^{\circ} \mathrm{C}, 80^{\circ} \mathrm{C}\right.$, microwave $)$ the sample honeys from different botanical origin behaved similar considering 5-HMF content and diastase activity and the fluorescence spectra. The values of 5-HMF content and diastase activity clearly indicate the process of overheating of honey, however not only the temperature of heating is important for created a quality of honey, but also a time of a heating.

3. The fluorescence spectra were the same for the honeys heated in $40^{\circ} \mathrm{C}, 60^{\circ} \mathrm{C}$, and in microwave oven. Only the fluorescence spectra for honeys heated in $80^{\circ} \mathrm{C}$ differ significantly. This means that fluorescence spectra can be used only to detect extreme overheating of honey.

\section{REFERENCES}

Al-Diab D., Jarkas B. 2015. Effect of storage and thermal treatment on the quality of some local brands of honey from Latakia markets. J. Entomol. Zool. Stud. 3(3), 328-334.

Bartakova K., Drackova M., Borkovcova I., Vorlova L. 2011. Impact of microwave heating on hydroxymethylfurfural content in Czech honeys. Czech J. Food Sci. 29(4), 328-336.

Dyrektywa parlamentu europejskiego i rady 2014/63/UE z dnia 15 maja 2014 r. zmieniająca dyrektywę Rady 2001/110/WE odnoszącą się do miodu, http://eur-lex.europa.eu/legal-content/ /PL/TXT/?uri=CELEX\%3A32014L0063, access: 06.03.2018. [in Polish]

Gębala S. 2009. Measurements of solution fluorescence - a new concept. Opt. Appl. 39(2), 391-399.

Gębala S., Przybyłowski P. 2010. Sposób identyfikacji odmian miodu. Polska. Patent nr 214784. [in Polish]

Kowalski K. 2013. Change of antioxidant activity and formation of 5-hydroksymetylofurfural in honey during thermal and microwave processing. Food Chem. 141, 1378-1382.

Lenhardt L., Bro R., Zekovic' I., Dramic'anin T., Dramic'anin M.D. 2015. Fluorescence spectroscopy coupled with PARAFAC and PLS DA for characterization and classification of honey. Food Chem. 175, 284-291.

Pasias I.N., Kiriakou I.K., Proestos Ch. 2017. HMF and diastase activity in honeys: A fully validated approach and a chemometric analysis for identification of honey freshness and Adulteration. Food Chem. 229, 425-431.

PN-88/A-77626. 1988. Miód pszczeli. [in Polish]

Rozporządzenie Ministra Rolnictwa i Rozwoju Wsi z dnia 30 lipca 2015 r. zmieniające rozporządzenie w sprawie metod analiz związanych z dokonywaniem oceny miodu. DzU z 2015 r., poz. 1173. [in Polish]

Śliwińska A., Przybylska A., Bazylak G. 2012. Wpływ zmian temperatury przechowywania na zawartość 5 -hydroksymetylofurfuralu $w$ odmianowych i wielokwiatowych miodach pszczelich [The effect of storage temperature changes on the content of 5-hydroxymethylfurfural in different botanical origin of honey and multiflorous honeys bees]. Bromatologia 45(3), 271-279. [in Polish]

Tosi E., Ciappini M., Re E., Lucero H. 2002. Honey thermal effects on hydroxymethylfurfural. Food Chem. 77, 71-74.

Tosi E.A., Re E., Lucereco H., Bulacio L. 2004. Effect of honey high-temperature short-time heating on parameters related to quality, crystallisation phenomena and fungal inhibition. Lebensm-Wiss. U. Technol. 37, 669-678.

Turhan I., Tetik N., Karhan M., Gurel F., Reyhan Tavukcuoglu H. 2008. Quality of honeys influence by thermal treatment. LWT 41, 1396-1399. 
Wilczyńska A. 2012. Jakość miodów w aspekcie czynników wpływających na ich właściwości przeciwutleniające. Gdynia, Wydaw. AM. [in Polish]

Abstract. The honey heating process used for its recrystallization (especially in a high temperatures and for a very long time) can result a chemical changes. The aim of this study was to use fluorescence spectroscopy to assess the grade of overheating of honey of different botanical origin. The sample was consisted of 20 honey samples of different botanical origin (rape, leaf honeydew, multifloral, pine honeydew, buckwheat), which were heated at various temperatures $\left(40^{\circ} \mathrm{C}, 60^{\circ} \mathrm{C}, 80^{\circ} \mathrm{C}\right.$ for 48 hours and microwave $-90^{\circ} \mathrm{C}$ in time up to 10 seconds). The prepared honey samples were evaluated by determining the 5-HMF content and the diastase activity by the spectrophotometric methods. Fluorescence spectra were also made, which allowed to distinguish samples of honey from the different botanical origin. As a result of various heating methods $\left(40^{\circ} \mathrm{C}, 60^{\circ} \mathrm{C}, 80^{\circ} \mathrm{C}\right.$, microwave), samples of honey from different botanical sources behaved similarly (the content of 5-HMF and diastase values and fluorescence spectra). The highest content of 5-HMF and the lowest diastase number had honey heated at $80^{\circ} \mathrm{C}$ - beside of the variety. By analyzing the fluorescence spectra, it can be seen that they were very similar for honeys heated at $40^{\circ} \mathrm{C}, 60^{\circ} \mathrm{C}$ and in a microwave oven. Only the fluorescence spectra for honey heated at $80^{\circ} \mathrm{C}$ differ significantly from the other samples. This means that fluorescence spectra can be used only to detect extreme overheating of the honey. 